\title{
EVALUATIVE PATTERNS IN THE OFFICIAL DISCOURSE OF Human Rights in Chile: giving value to the PAST and BUILDING HISTORICAL MEMORIES IN SOCIETY
}

(Patrones valorativos en el discurso oficial de Derechos Humanos en Chile: dando valor al pasado y construyendo memorias históricas en la sociedad)

(Padrões valorativos no discurso oficial de Direitos Humanos no Chile: dando valor ao passado e construindo memórias históricas na sociedade)

Teresa Oteíza S. (Universidad Austral de Chile)

\begin{abstract}
This paper analyzes certain patterns of voice realization of the Chilean National Truth and Reconciliation Commission of 1991, established after the end of the military dictatorship (1973-1990). In this official document, produced and promoted by the Chilean Government, the authors strive to present themselves as powerless to judge society or to explain historical events. However, they propose evaluations (evoked and inscribed) of relevant sectors of society, offer an interpretation of history, and specifically, give explanation for the "military intervention" and the possible causes for the severe buman rights violations during the dictatorship. Informed by the complementary theoretical approaches of SFL and CDA, I focus on Appraisal analysis (White 2000, 2003; Martin 1997, 2003, 2004; Martin E Rose 2003; Martin E White 2005) and a transitivity analysis of mental and verbal projections in the discourse, as tools for a more flexible and detailed exploration of the use of evaluation resources. This analysis allows us to create a systemic network of the patterns of grammatical and lexical resources used by the Commission to generate mitigation and selflothers representation in the discourse. This linguistic analysis, inserted in a social practice, also offers a complementary understanding of the subjectivities found in the field of oral bistory, specifically in the study of testimonies that account for different and contradictory memories of the recent Chilean past (Stern 2006).
\end{abstract}

KEY-WORDS: Appraisal theory, buman rights, voice, historical memories

D.E.L.T.A., 25:EsPECIAL, 2009 (609-640) 
RESUMEN: Este artículo analiza algunos patrones de la realización de voz de la Comisión Nacional de Verdady Reconciliación chilena de 1991, establecida después de la dictadura militar (1973-1990). En este documento oficial, producido y promovido por el gobierno chileno, los autores procuran presentarse a sí mismos sin poder para juzgar a la sociedad o para explicar los eventos históricos. Sin embargo, ellos proponen evaluaciones (evocadas e inscritas) de sectores relevantes de la sociedad, ofrecen una interpretación de la historia, y específicamente, dan una explicación para la "intervención militar" y las posibles causas para las graves violaciones a los derechos humanos durante la dictadura. Este trabajo se fundamenta en los enfoques teóricos complementarios de la LSF y el ACD, y se centra en el análisis de la valoración (White 2000, 2003; Martin 1997, 2003, 2004; Martin E Rose 2003; Martin E White 2005) y el análisis de la transitividad de las proyecciones mentales y verbales en el discurso, como herramientas para un examen más flexible y detallado del uso de los recursos de valoración. Este análisis nos permite crear una red sistémica de patrones de recursos gramaticales y léxicos usados por la Comisión para generar atenuación en la representación de sí misma y de otros en el discurso. Este análisis lingüístico, inserto en una práctica social, ofrece asimismo una comprensión complementaria de las subjetividades encontradas en el campo de la bistoria oral, específicamente en el estudio de testimonios que dan cuenta de memorias diferentes y contradictorias del pasado reciente chileno (Stern 2006).

PALABRAS-CLAVEs: Teoría de la Valoración, derechos humanos, voz, memorias históricas.

Resumo: Este artigo analisa alguns padrões da realização de voz da Comissão Nacional de Verdade e Reconciliação chilena de 1991, estabelecida depois da ditadura militar (1973-1990). Neste documento oficial, produzido e promovido pelo governo chileno, os autores procuram apresentar-se a si mesmos sem poder para julgar a sociedade ou para explicar os acontecimentos históricos. Entretanto, eles propõem avaliações (evocadas e escritas) de setores relevantes da sociedade, oferecem uma interpretação da história, e especificamente, dão uma explicaşão para a "intervenção militar" e as possiviveis causas para as graves violaçoes aos direitos humanos durante a ditadura. Este trabalho fundamenta-se nos enfoques teóricos complementares da LSF e o ACD, e centra-se na análise da valoração (White 2000, 2003; Martin 1997, 2003, 2004; Martin E Rose 2003; Martin E White 2005) e na análise da transitividade das projeções mentais e verbais no discurso, como ferramentas para um exame mais flexível e detalhado do uso dos recursos de valoração. Esta análise permite-nos criar uma rede sistémica de patrões de recursos gramaticais e léxicos usados pela Comissão para gerar atenuação na representação de si mesma e de outros no discurso. Esta análise lingüística, inserta numa prática social, oferece, igualmente, uma compreensão complementar das subjetividades encontradas no campo da história oral, especificamente no estudo de testemunhos que dão conta de memórias diferentes e contraditórias do passado recente chileno (Stern 2006).

Palavras-chaves: Teoria da Valoração, direitos humanos, voz, memórias históricas. 


\section{Introduction}

This paper analyzes certain evaluative patterns of voice realization of the Chilean National Truth and Reconciliation Commission of 1991, created after the end of the military dictatorship (1973-1990). In this official document, produced and promoted by the Chilean Government to establish the truth about human right violations during Pinochet's dictatorship, authors strive to present themselves as powerless to judge society or to explain historical events. Nevertheless, they propose evaluations (evoked and inscribed) of relevant sectors of society, offer an interpretation of history, and specifically, give an explanation for the "military intervention" and the possible causes for the severe human rights violations during the dictatorship.

I am interested in exploring how hegemonic and counter-hegemonic explanations compete to establish their memories of the past in the discourse. These positions have the potential to install ways of explaining the events that polarized the country, which are currently represented in the public sphere by a consensus that doesn't necessarily recognize alternative positions. As Wodak and Cilia (2007) point out, the selection of past events is carried out by those who have the power, and in a way that they (the events) could be useful to the construction of present and future interests, as forms of self-representation, as well as educational instances that create consensus about common values. The discipline of history is intrinsically a political activity in which it is impossible to avoid partiality in relation to the events narrated because the production of historical knowledge implies, necessarily as Fontana (1992) explains, the construction of an interpretation of the facts, from the selection of sources onward.

From a CDA perspective, little research has been done regarding a detailed lexicogrammatical analysis, since the studies have been mainly focused on macro-discursive strategies or argumentative patterns (Martin \& Wodak 2003), although several researches in the last years have made valuable research in CDA with a detailed lexicogrammatical analysis (Achugar 2004, 2008; Butt, Lukin\& Matthiessen 2004; Montecino 2008; 
Oteíza 2003, 2006, forthcoming; Oteíza \& Pinto 2008, among others). Consequently, this study seeks a better understanding of the functioning of subjective meanings in the discourse, and I intend to offer a solid analysis that contributes to our comprehension of how certain explanations about the past are built in the discourse as well as the mechanisms of perpetuation, generalization and simplification (Benke \& Wodak 2003) that help to create an ideological solidarity between writers and readers resulting in a discourse of consensus in the social imaginary.

The linguistic analysis, inserted in a social practice, also has the potential to contribute as a pedagogical resource for teachers and students. I believe that it is important to study history in order to humanize society, however, when we cannot recover the experiences and the human beings that were part of them in critical and reflexive ways, the past can become an alienate space.

This paper is organized in the following sections: First, it starts with a concise discussion of the complementary approaches of SFL and CDA, arguing that an Appraisal theory can be used as a powerful theoretical and methodological tool to better understand social problems with their representation in discourse, and focusing further on the analysis of evaluative resources and on how they work in the discursive-semantic meaning stratum. Secondly, I continue with a brief historical and political background that, I hope, will contribute to situate the context of production of the Commission Report and its socio-political impact regarding human rights violations in Chile. Third, I present the discursive analysis itself, providing examples from the first volume of the Commission Report to show how the different linguistic resources work together to create patterns of subjectivities that the Commission use to generate mitigation, justification, self and others representation and ideological solidarity, among other strategies in the discourse.

Finally, I show how specific lexicogrammatical resources work together in Spanish in a continuum of evaluative sources that authors use to express more or less monoglossic or heteroglossic positions, creating different types and levels of alignment between writers and readers. With this analysis I aim to offer a complementary understanding of the subjectivities found in the field of oral history, specifically in the study of testimonies that account for different and contradictory memories of the recent Chilean traumatic past (Stern 2006). 


\section{Analytical framework}

This analysis is informed by the complementary theoretical approaches of SFL and CDA, focusing on Appraisal theory (White 2000, 2003; Martin 1997, 2000, 2003a,b, 2004a,b; Martin \& Rose 2003; Martin \& White 2005). Due to the sociosemiotic perspective of SFL that considers language as part of a human activity, that is, as a social practice in a specific community, it is possible to systematically relate language with the social and cognitive experience of those who build reality with and within it. From the multidisciplinary CDA approach, discourse is also understood as a social practice of meaning-creation with language (spoken, written or other symbolic systems in particular situations); the discourse is thus, constitutive and constituted by political and social realities (Fairclough \& Wodak 1997; van Leeuwen \& Wodak 1999). In this sense, both the discursive formations (Foucault 1972) and the thematic patterns (Lemke 1995) are social practice, not individual acts of intentionality. They are also necessarily intertextual, since the same patterns are repeated from one text to another with forms of expression that are slightly different, yet recognizably similar. In discourse, cultural models and socially shared beliefs are manifested and reproduced, ruptures, oppositions and dichotomies are projected, and possibilities of dialogue with other discourses are created. This intertextuality as Lemke (1995) has emphasized, is neither a relation between linguistic forms nor individuals, but between points of view.

On the other hand, the Appraisal theory is a reorientation of Halliday's legacy (1994) and his work on mood and modality developed as part of the theoretical frame of the SFL. The main purpose of Appraisal theory has been to present a comprehensive and systematic reorganization of the linguistic resources that can be used to value the social experience. This objective responds, in part, to the growing interest in research that examines how language builds social roles and the potential these roles have to operate rhetorically and generate an influence in beliefs, attitudes, expectations and ways of maintaining relationships (White 2003:259).

This theoretical and methodological tool allows us to analyze the subjectivization of author's voices that in turn contributes to our understanding of the levels and types of ideological solidarity that authors maintain with their potential readers. As Martin (2004b) expresses, evaluation has a constructive role in social organization in the sense that it 
shows how we share feelings in the discourse in order to generate social belonging, which at the same time, has the potential to naturalize readers' positions. The Appraisal theory is incorporated into the theoretical CDA approach as a tool for a more flexible and detailed analysis of linguistic (lexico-grammatical and discourse-semantics) and key discursive strategies used by authors to build value judgments, including more metaphorical realizations of interpersonal meanings that implicitly evoke particular evaluations without having them inscribed in the text. The grammatical resources work in combination with lexical codifications of interpersonal meanings both at a more global or macro level and at inter and intra clausal levels. This is so because this theory considers evaluation in a conceptual manner, that is, every element, discrete or not, is a potential instance of subjectivity in a text. In other words, this theory regards interpersonal meanings as a prosody that works in an accumulative way to create flows of evaluative patterns in the discourse. As Hunston and Thompson, as well as other linguists have emphasized, "it is clear -and all the studies about evaluation have said so- that evaluation tends to be found throughout the text rather than being confined to one particular part of it (2000:19)

In this Appraisal theory ideational and textual meanings are also necessarily considered because they contribute to the interpersonal meaning or they are built simultaneously to the interpersonal meaning in the discourse. Consequently, the ideational choices indicate valuations of Attitude, which rarely are neutral but rather evoked. Figure 1 provides a general outline of the Appraisal theory.

Although I will consider the three subsystems in my analysis, I am especially interested in the subsystem of Engagement, the system that helps us explore the source of evaluations. The theoretical development of this system has received a strong influence from Bakhtin ${ }^{1}$ regarding the dialogic nature that all texts have towards other utterances that are represented with different levels of "otherness" in the discourse. White (2000) proposes, therefore, that meanings can be oriented to more monoglossic or heteroglossic positions depending on whether or not the authors recognize alternative positions in the discourse in relation to specific

\footnotetext{
${ }^{1}$ The heteroglossic perspective on evaluation in popular science was incorporated to the Appraisal
} theory by Gillian Fuller, PhD Dissertation directed by James Martin (Martin \& White 2005: xi). 
Oteíza: EVAluative PATteRns IN THE OFFICIAL DisCOURSE OF HUMAN RIGHTS... 615

\begin{tabular}{|c|c|c|}
\hline \multirow{7}{*}{ APPRAISAL } & \multirow{2}{*}{ ENGAGEMENT } & $\begin{array}{l}\text { Monogloss (Authors do not recognize alternative } \\
\text { voices) }\end{array}$ \\
\hline & & Heterogloss (Authors recognize alternative positions) \\
\hline & \multirow{3}{*}{ ATTITUDE } & Affect: Un/Happiness, In/Security, In/Satisfaction \\
\hline & & Judgement: Social Esteem and Social Sanction \\
\hline & & $\begin{array}{l}\text { Appreciation: Reaction, Composition and Social } \\
\text { Valuation }\end{array}$ \\
\hline & \multirow{2}{*}{ GRADUATION } & Force: raise/ lower \\
\hline & & Focus: sharpen/ soften \\
\hline
\end{tabular}

Figure 1: General outline of the APPRAISAL System according to Martin \& Rose 2003; Martin \& White 2005.

evaluations. The grammatical resources that authors have at their disposition to express one orientation or another will vary according to the types of genres and registers in which they take place. For example, the meanings of obligation (modulation) and negative polarity tend to be employed as expressions of monoglossia in the Chilean pedagogical discourse of history generating consensual ('accepted' or 'non problematic') knowledge that naturalizes and simplifies the explanations of the past (Oteíza forthcoming).

Following a Bakhtinian perspective, White makes an important distinction between epistemic and dialogic modality that helps us conduct our analysis of Engagement with a more social-dialogic point of view, which gives us room to consider readers' positions. (See Figure 2):

White (2003) argues that these resources can be classified as dialogically expansive or dialogically contractive. The heteroglossic perspective implies that the speaker places himself or herself in heterogeneous social positions and world conceptions. When authors use an affirmative utterance, they adopt a specific rhetoric strategy to make the heterolossic diversity possible, in particular one that chooses not to recognize directly this possibility, that is, one that assumes a homogeneous speaking community instead of a heterogeneous one (White 2000). 


\begin{tabular}{|l|l|}
\hline Epistemic Modality $\rightarrow$ & $\begin{array}{l}\text { Veritative and individualist perspective: } \\
\text { Type of semantic that relates to the mode in which individual } \\
\text { speakers present themselves with or without willingness to } \\
\text { compromise themselves with the truth of what is asserted in } \\
\text { relation to a specific propositional content. }\end{array}$ \\
\hline Dialogic Modality $\rightarrow$ & $\begin{array}{l}\text { Social perspective: } \\
\text { The audience (concrete or potential) has a more important role. } \\
\text { The meaning is built in social terms. }\end{array}$ \\
\hline
\end{tabular}

Figure 2: Differences between epistemic and dialogic modality according to White $(2000,2003)$.

I would like to make two final distinctions before we advance to the political and historical background and the Report's analysis. This Appraisal theory considers evaluation as a discursive semantic system. In this sense we are referring to what Halliday (1994) distinguishes as levels of realization or scale of abstraction. The discursive semantic stratum is realized on a more "concrete" level": the lexicogrammatical one. Accordingly, it is important to carefully analyze how the evaluative meanings are realized at this level (if we are to analyze oral speech we would also be looking at a phonetic level). On the other hand, it is also important to situate our analysis on a cline of instantiation or levels of generalization. At this point in my research on official historical documents I am not able to talk about evaluative key (Martin \& White 2005) because that implies an analysis at the register level, that is of "situational variants or sub-selections of the global evaluative meaning making potential-typically reconfiguration of the probabilities for the occurrence of particular evaluative meaning-making options or for the co-occurrence of options." (Martin \& White 2005:164). I hope to do this later on when I have more research done (qualitatively and quantitatively). For now I can offer a situated analysis at a text-type level and show how the system (Appraisal theory) is instantiated into subchoices of patterns of evaluative options with particular rhetorical objectives, also taking into consideration the last level of this cline of instantiation: reading, or "the attitudinal positions activated by the reader as a result of their interaction with the text" (cf. 164).

A last, but relevant distinction: ideology and axiology. Graham (2004) and Martin (2004b) have pointed out, with different purposes, the 
theoretical value of these two concepts. As Martin states, considering ideational meanings and interpersonal meanings as ideology and axiology respectively in Bakhtin's terms "has the advantage of denaturalizing the ideational as political (ideology), and foregrounding intersubjectivity evaluation over interaction (axiology)" (2004:337). This conceptualization works better with an Appraisal theory and its Engagement subsystem that considers monoglossia and heteroglossia as options that are both of a dialogic nature. Graham (2004), interested in providing a more rigorous connection between SFL and CDA, emphasizes the need to analyze how axiologies or evaluative-meaning systems are inculcated, maintained and changed over time and the role of mediation as essential to the analysis of meaning.

In the analysis of the Rettig Report written by the Chilean National Truth and Reconciliation Commission I will attempt to demonstrate that evaluative meanings used to justify and explain the coup d'etat of September 11, 1973 and the consequent human right violations have remained the same over time; at least the ones that the official voices have been inculcating by means of repetition in the Chilean pedagogical discourse of history. (Oteíza 2003; 2006; Oteíza \& Pinto 2008).

\section{Political and historical context for the Chilean National Truth and Reconciliation Commission Report (1991)}

I would like to provide a brief historical background to situate the analysis of the Report of the Chilean National Commission on Truth and Reconciliation of 1991. Salvador Allende, who was elected president by a democratic election in 1970, represented a political coalition from the left denominated Popular Unity (Unidad Popular). Allende proposed "a peaceful road to socialism" which did not consider an armed struggle as other revolutions in Latin America. He and the Popular Unity coalition that he represented desired to carry out several social and economic reforms and attempted a massive income redistribution program to benefit the poorest sectors of Chilean society. His government was seen as unique and caused expectation in many countries, but also evoked intense hostility from the United States and the Right and Center political sectors of Chilean society. Allende's government encountered several problems that from the beginning made this "Chilean path to socialism" a very difficult enterprise. 
Many pages have been written to analyze the causes for the Allende government's failure and they have raised important theoretical questions for socialist intellectuals and politicians about the viability of a peaceful road to socialism. Some make the ultra-leftists responsible, while others appeal to unrealistic economical policies and bad politics that prevented reconciliation and compromise with the Christian Democrats (Center), however, both make Allende and his administration the main responsible political group for "the military intervention". Other sources emphasize the enormous opposition that the Unidad Popular faced since Allende won the Presidential election in 1970 that contributed to create an economic and political crisis.

It is important to take into consideration that Allende's and the Popular Unity's victory happened during the years of the so called Cold War, and thus, his government was considered part of a global conflict between the US and URSS. Therefore, it was seen by the Center and the Right as a threat to democracy and as a potential prelude to a "Marxist dictatorship". Allende's government was boycotted by the Chilean Right with economical and political support from USA, even before he assumed as president. As Loveman states: "Congressional investigations in the United States have made available incontrovertible evidence of extensive U.S. efforts to undermine the Allende government. (...) After Allende took office, U.S. policies, both covert and overt, contributed significantly to the government's economic woes and to the political polarization that eventually culminated with the military coup on September 11, 1973." (2001:257).

On September 11, 1973 a violent coup d'etat lead by Augusto Pinochet took control of the country and caused President Salvador Allende's death. During the first days and following months, thousands of Chileans were detained, tortured and killed in improvised detention centers across the country, many of them disappeared. The main victims, although not the only ones, were socialists, communists and miristas' militants and other Chileans or foreign people considered "subversive" to the new military regime. The military coup d'etat had an enormous impact among Chileans and the rest of Latin America. For the opponents of the Popular Unity government, it was a day of liberation, but for its supporters it was a day of grief and fear. As Stern (2006) states, the events that started on September 11 are remembered by Chileans as "salvation", "rupture", "persecution and awakening", and as a "closed box", which constitute key social referents 
for young generations to understand how different social actors give value and meaning to the past.

In spite of the different historical memories that Chileans may have, the establishment of truth and justice regarding the severe human right violations and repression that Chileans lived specially during the first years of the seventeen that the Pinochet's dictatorship lasted, were one of the most important and urgent responsibilities that the first democratic government had in 1990. Thus, the President Patricio Aylwin, who attempted to promote a politics of consensus and a "pacific reencounter among Chileans", promulgated on April 25th, 1990 the Decree 355 that created a National Commission on Truth and Reconciliation (nick-named the Rettig Commission, for it director Raúl Rettig, a Radical party politician) to investigate human rights violations during Pinochet's dictatorship. The Commission was exempt from individualizing responsibilities and "serving/ doing" justice. The main objective was "to contribute to the global clarification of the truth about the most severe human right violations committed in the last years, inside the country or abroad, if they have a relation with the Chilean State or with the national political life, with the objective of collaborating with the reconciliation of all Chileans, and without taking into consideration the law procedures to which those events can lead." (Decree 355, First Article)

The Commission was formed by a group of "prestigious people" from the country that had the "moral authority" to receive and analyze all the antecedents that they could collect about the most severe human right violations. It was formed by eight people: six men and two women, seven lawyers and politicians and one social scientist. All but one belongs to the Right and the Center, no one belongs to the Left. It is relevant to note that one of the members of the Commission was Gonzalo Vial, a lawyer who has been writing as a historian for decades in newspapers, textbooks and books for general and specialized public, and who was Minister of Education during Pinochet's dictatorship and a strong opponent to Allende's government. Even more crucial, in 2003 he admitted to being the principal author of the "Plan Zeta" published in the "White Book" of the dictatorship; this plan was a supposed plot of the extreme left to impose communism definitely upon Chile. This is relevant because, although years later it was proven that this Plan Zeta was invented by the dictatorship to justify the coup d'etat, during the early seventies it was a serious rumor that 
contributed greatly to the crisis, the violent climate that the country lived, and worse, it was a justification for the thousands of people who were brutally tortured, killed and/or 'disappeared' especially during 1973.

\section{Analysis and discussion}

For this section I have chosen what I believe are representative passages that show how authors build the flow of evaluative meanings interwoven with the ideational and textual meanings. I analyzed from the first volume of more than 400 pages, the Introduction and Political Frame sections of the Rettig Report (approximately 30.000 words). I tried to respect the original arrangement of the document; however, to better present and organize the evaluative patterns, I decided to change the order of some of the examples ${ }^{2}$. I will highlight only certain evaluative resources each time to be able to explain them, understanding that Appraisal does not work in a discrete manner but rather as a prosody as it was previously mentioned.

\subsection{Commission Self-presentation: moral status, objectivity and limitations}

These are examples from the "Exordio" (Introduction) to the Rettig Report where members of the Commission explain their reasons for accepting to be part of it, its role and limitations. The Report starts with the following words:

(1) Nos permitimos decir por qué aceptamos el noble cometido con que se nos bonró. Sabíamos de sus dificultades y cómo a ellas se aliaban nuestras propias limitaciones. Aceptamos, a pesar de ello, sin vacilar. Somos un grupo cuyos componentes sustentan diversos pensamientos explicativos de la vida. Nos sabemos cultores de diversas tradiciones, adberimos a distintas posturas políticas y juzgamos en forma diversa los contenidos de nuestra historia. (p.xiv)

(1) We allow ourselves to say why we accepted the noble task with which we have been honored. We knew that it would be difficult, and that our own limitations would make it more so. We nonetheless accepted it without hesitation. We are a group whose mem-

\footnotetext{
2 Three bilingual (Spanish-English) historians helped with this translation. We tried to maintain the original language and be as literal as we could to respect the grammatical structures and words chosen in Spanish, but this resulted in a less fluent translation.
} 
bers hold a variety of philosophies of life. We are aware that we possess diverse traditions, that we adhere to different political positions, and that we have different perspectives on our country's history. (p.xiv)

(2) Creemos, sí, en la identidad esencial de nuestra Patria y pensamos que ella debe ser protegida por un Estado que permanezca fiel a las normas de la Democracia (...) Aceptamos porque a todos nos une el mismo principio fundamental: el respeto a la persona bumana por el hecho de serlo y el de considerarla amparada por derechos inalienables que ninguna. circunstancia adjetiva, nacionalidad, credo, raza o ideología, puede válidamente autorizar que se conculquen. Derechos son éstos que ningún poder, sean cuales sean sus alcances, puede atropellar. Nos une la total convicción que ve en el ser bumano y en su dignidad los límites infranqueables al actuar de otros hombres. Esa es la norma primacial de la convivencia humana. Nos une, finalmente, el anbelo de hacer de nuestra Patria una tierra digna de albergar a bijos de nuestra especie, señalada siempre como la expresión más alta de lo creado. (p.xv)

(2) We do believe in the essential identity of our Fatherland, and we think it should be protected by a state that remains faithful to the norms of democracy (...). We accepted four task). because the same fundamental principle unites us all: respect fro buman beings simply because they are human beings - and because we believe that the individual is protected by inalienable rights which cannot be violated on the grounds of any limiting condition, nationality, creed, race, or ideology. These are rights that no power, no matter how far-reaching, may violate. We are united by a total conviction that the human being and his tor hert. dignity constitute inviolable limits to the activity of other buman beings. This is the preeminent (supreme or primordial) rule of human coexistence. Finally, we are united in the desire to make our Fatherland a land worthy to shelter the children of our species, which is always regarded as the bighest expression of creation. (p.xv)

(3) Nos pareció, también, que mantener estos hechos dolorosos en un silencio, más forzado que real, no contribuía a la buena convivencia futura en nuestra patria. Estimamos, por el contrario, que colaborar con el Estado de Chile en el establecimiento de la verdad de un modo sereno e imparcial serviría a que la sociedad asumiera una actitud de reconocimiento de esos hechos y que se iniciara de este modo el asentamiento de una buena motivación en contra de futuros atropellos. Así, los dolores del pasado, junto con promover el afán común de condenar lo indefendible, aportarían su fecundidad a la obligación de evitar la repetición de lo ocurrido y provocarían, en tal sentido, un consenso promotor de la reconciliación deseada. (p.xv)

(3) It also seemed to us that to maintain these painful events in silence, more forced than real, would not contribute to a good future coexistence in our Fatherland. We considered, on the other hand, that to help the Chilean state to establishing the truth in a calm and impartial manner would be belpful for society to adopt an attitude of acknowledging of those facts and initiate in this way the establishment of a bealthy resistance against future violations. The pain of the past, together with a common desire to condemn that which is indefensible, will belp prevent the repetition of such events, and would lead, thus, to a consensus that might be conducive to the reconciliation we all desire. (p.xv) 
In these three examples we can appreciate a Commission that positions itself through mainly mental clauses and relational clauses (example 1) from a 1pplural "we" emphasizing the ideological differences that they have (although they represented only the Center and the Right political spectrum of the country). This focus on differences is going to serve as a powerful device to portray their objective position in the discourse that goes beyond possible competing perspectives. Example (2) shows a Commission that explicitly expresses what unites them as a group: the moral duty of protecting fundamental human rights that every human being should have. In this example, the role of Graduation by means of adjuncts and epithets is crucial in the portrayal of the ideational meaning about basic human rights that are 'inalienable'. The evaluative prosody works mainly as a saturated prosody, as in many other passages of the Report.

What I think is less noticeable but relevant is the more covert role of evaluation of Affect in examples (2) and (3): el anhelo/ the desire; estos hechos dolorosos/ these painful events; los dolores del pasado/ the pain of the past. They all allude to, for one part, a positive AFFECT expressed as a wish desired, and to a negative AFFECT of the events and pains that we as society desire to avoid. The strong use of nominalizations makes this evaluation less noticeable as in: el anbelo de hacer de nuestra patria.../ the desire to make our Fatherland... These evaluations of AFFECT may be more evoked because they are referring to a moral duty that is essential; it is a value that does not need to be argued about. These little and more evoked AFFECT evaluations also serve the Commission's purpose which was to present themselves as 'objective' and 'serene' (not guided by their feelings). In these introductory words of the Report, it is possible to see how ideological and axiological meanings are going to work together to build a strong feeling of belonging to a moral duty that is based on fundamental convictions. They are an example of the 'reflection' that the country needs to do to overcome this painful past as I will try to show later on in the analysis.

(4) La labor de la Comisión era establecer un cuadro lo más completo posible sobre las más graves violaciones a los derechos bumanos con resultado de muerte y desapariciones cometidas por agentes del Estado o por particulares con fines políticos; (...). (p.xv)

(4) The Commission's task was to draw up a picture as complete as possible of the most serious human rights violations that resulted in death and disappearances which committed by State agents or by private citizens for political purposes (...). (p.xv) 
In this example the Commission positioned themselves as serving a role whose limitations and scope of action is not their responsibility because it was established by the Chilean Government and by the Decree that created this Commission. They are part of a prepositional phrase that is modifying the noun "role", all functioning as an Indentified of an Identificative relational process "was". Their role, of course, comes from an external source.

(5) Pusimos en nuestro trabajo el propósito más puro de imparcialidad. Fuimos, por consiguiente, objetivos y nos preciamos de haber puesto en ello rigor y comprensión a la vez. Nadie podrá sostener que bemos inclinado nuestra ponderación en función de prejuicios 0 banderías. En todas nuestras decisiones bubo consenso alentador. (p.xv)

(5) We put ion our work the purest purpose of impartiality. Hence we were objective, and we pride ourselves on having been both rigorous and understanding. No one will be able to bold that we have been swayed in our deliberations by prejudices or loyalties to particular groups. It was encouraging to find ourselves agreeing on all our decisions. (p.xv)

Example (5), shifting again to a first plural person "we", shows clearly that they strive to present themselves as objective and rigorous. This is explicitly done by Graduation (epithets) and by nominalizations and lexis with attitudinal meaning. This desire of presenting themselves as objective is emphasized by the statement that nadie podrá sostener / no one will be able to hold. The use of the modal podral will be able in future tense gives it a stronger meaning because it is more than expressing a possibility, it carries a meaning of obligation, a strong deontic command precisely due to the future tense in a negative verbal clause that determines the meaning of the projected verbal clause.

\subsection{Chileans' responsibility}

(6) El Estado de Chile ha de volcarse hacia ellos (parientes de las víctimas) y obtener su perdón para la sociedad que los hirió. Esta debe imbuirse de lo ocurrido para poder mirar limpiamente el futuro. Si reconstituir la verdad ha sido una ardua tarea para esta Comisión, emplearla para la Reconciliación Nacional es un delicado y fundamental deber de todos los chilenos. (p.vii)

(6) The Chilean state must turn to them and obtain from them their forgiveness for the society that injured them. It must imbue itself with what happened to be able to look 
forward to the future with clear conscience. If the Commission has had the arduous task of reestablishing the truth, it is a delicate and fundamental duty of all Chileans to utilize the truth for the sake of National Reconciliation. (p.vii)

(7) Creemos firmemente que los chilenos hemos de coger de esa verdad lo que nos hace responsables a todos y a cada uno; entender que la violencia represiva y la extremista tienen aspectos que no sólo han de pesar sobre las conciencias de los autores directos de los crímenes. Lo contrario sería estrechar la visión con que bemos de abarcar el significado de lo que pasó. La verdad es que el anbelo de evitar su repetición requiere de una actitud espiritual distinta. (p.xvii)

(7) We firmly believe that we Chileans must seize hold from this truth that which makes each and every one of us responsible; we must understand that there are some aspects to both repressive and extremist violence not only will the weight upon on the consciences of those directly responsible for the crimes. To do otherwise would be tantamount to narrowing the vision with which we must apprebend the meaning of what happened. The truth is that the desire to avoid its repetition requires a different spiritual attitude. (p.xvii)

(8) Tal actitud es la de reflexionar con devoción cívica acerca de cómo hemos de comportarnos en el futuro. De esa reflexión debe arrancar el convencimiento cabal que lleve a la certeza de ser la plenitud democrática y el Estado de Derecho los únicos diques capaces de contener la violencia, de bacerla inútil y de proscribirla de manera permanente. Sólo así el país estará a salvo de nuevas manifestaciones que hagan de la fuerza ilegítima la rectora de la convivencia y del crimen el recurso habitual de los disidentes. Meditación y educación orientadas al entendimiento entre los chilenos son las obligaciones imperiosas que nos impone el examen de la secuencia de tragedia que hemos debido exponer. (p.xvii)

(8) Such an attitude entails reflecting with civic devotion on how we must conduct ourselves in the future. That reflection should lead to an utter conviction that full democracy and the rule of law are the only dikes that can contain violence, render it useless, and banish it forever. Only in this fashion will our country be secure from new outbreaks that might give lawless force control over our life in common and incline dissidents to routinely resort to criminal behavior. Meditation and education oriented toward an understanding among Chileans are the imperative obligations that are imposed on us by an examination of the sequence of tragedy which we have had to expose here. (p.xvii)

The Chileans' responsibility towards human right violations is constructed in the discourse with inscribed evaluations that signal how they have to think, feel and behave about it. Examples (6) and (7), I believe, are especially interesting due to the grammatical structure that the authors use to express meanings of obligation through modal verbs (modulation). 
Note the use of the form: HABER + DE + VERB (infinitive). These have a kind of meaning of: "HAVE TO" or "NEED TO" that allude, as Bartlett (2004) states, to an external force, to an essential repair; we can also read this as a SHOULD that accentuates the meaning of the appropriate, as a correct action. This use of obligation meanings emphasizes the moral nature of the obligation that is 'imposed' on the Chileans as a whole, and thus, it is more difficult to reply with alternative positions. However, this peripherical manner also makes the obligation meaning more impersonal, presented as a given, and thus, in a way we can interpret this as 'less imposing' because it appeals to a "natural" moral alignment. In example (8) the use of "we" and a behavioral process makes this obligation meaning more likely to be taken with this moral alignment (cómo hemos de comportarnos/ how we must conduct ourselves). The meaning of obligation is also expressed by nouns and processes that carry this ideational sense amplified by resources of Graduation (delicate and fundamental duty of all Chileans; the imperative obligations).

All Chileans are presented as responsible for the repressive and extremist violence. Society and Chileans are portrayed as responsible as President Aylwin (1990-1994) expressed it in his speech when he announced the creation of this Commission. This obligation is graduated by adjuncts and epithets in the discourse emphasizing Chileans' reflection as a necessary step toward reconciliation (expressed by identificative sentences at the end of example (7) and the beginning of example (8)) that emphasizes the expression of a nominalized positive AFFECT with a Relational Process typical of this type of sentence: La verdad es que el anhelo de evitar su repetición require de una actitud espiritual distintal The truth is that the desire to avoid its repetition requires a different spiritual attitude.

The opposites are presented in a generalized manner as disidentes/ dissidents who have a clear negative connotation of SOCIAL SANCTION of propriety: they cause violence. Their presentation is blurry and will be associated with difficulty, for instance with the Armed Forces or the extreme Right, but more easily with the extreme Left. This indirect or evoked interpretation is validated if we examine this Report from a logogenesis perspective and how this evoked meaning or association has been primed in Chileans' perspective over a long period of time (a corpus analysis that takes into consideration larger amount of corpora and intertextual analysis combined with detailed analysis will help to avoid the analysts bias as Coffin and O'Halloran (2006) point out). 
Finally, it is also important to note how what happened is packaged in these examples. I will discuss in more detail how different key historical events are represented reiteratively throughout the discourse in the next section.

3.3. The past: Allende's government crisis, Coup d'etat and human right violations.

(9) Hemos considerado nuestro deber incluir referencias a las circunstancias que vivió el país el 11 de septiembre de 1973, pues, aunque nada justificara las violaciones que relataremos, ello contribuirá a recordar el ambiente en el cual ellas pudieran encontrar alguna de sus raíces. (p.xv)

(9) We have considered it our duty to include references to the circumstances that the country lived through on September 11, 1973, because, although nothing could justify the violations we will relate, this will help to remember the environment from which these violations could find some of their roots. (p.xv)

(10) Hemos establecido casos de muerte y desapariciones. En los primeros días posteriores al 11 de septiembre de 1973 se registraron caídos en enfrentamientos y víctimas de la violencia politica de ambos bandos. A ellas, siguieron ejecuciones de varios centenares de prisioneros políticos. Muchas de éstas fueron oficialmente explicadas en versiones que la Comisión no ha podido considerar aceptables o convincentes. Los cuerpos fueron con frecuencia abandonados u ocultados, produciéndose así las primeras desapariciones. Los hechos no fueron judicialmente investigados o sancionados. (p.vi)

(10) We have established cases of death and disappearances. In the days that immediately followed September 11, 1973, there were victims in confrontations and political violence on both sides. Later, this was followed by executions of several hundred political prisoners. Many of these executions were explained in official versions that the Commission bas not been able to consider acceptable or convincing. The bodies were often abandoned or bidden, thus yielding the first disappearances. These incidents were not subjected to official investigation or judicial action. (p.vi)

Authors continue to use the first plural person with mental clauses. It is also possible to say, that the use of imperfect of subjunctive in example (9) in the modal verb pudieran / could (function with a meaning of possibility or modality) puts this argument as a type of "irrealis" that is emphasized by "some". Different than nada justificara / nothing could justify, the adjunct nothing/ nada is strong, but I believe that is not strong enough to diminish the meaning of potentiality/ 'irrealis' of the justificara (imperfect 
subjunctive). This use of imperfect of subjunctive "justificara" attenuates the explanation the Commission is going to offer later on the "Political Frame". The subjunctive functions as a mitigator of the force of the assertion. In addition, the way that they naturalize the discourse of "what happened" on September $11^{\text {th }}, 1973$ is noticeable. We will see that this "environment" is understood as "knowledge", as a fact that, while it does not justify the severe human right violations, it helps to "understand" their "roots". The circumstances are narrated as a fact that the country lived, as a generalization.

Another crucial resource for portraying evaluation in these passages is the use of reflexive passive as we can see in example (10). The reflexive passive in Spanish (Produciéndose or se produjeron / yielding, causing and se registraron / there were) constructs discourse in a more active manner than passive clauses with verbs in passive voice because they are centered in the action of the verb more than in the possible people that were involved. These verbs work almost as an Existential process in conjunction with the use of passive voice twice. Note the active voice of the Commission (Actor of a Material/ Senser of a Mental Process). The use of nominalizations ejecuciones de varios centenares de prisioneros politicos / executions of several hundred political prisoners; casos de muerte y desapariciones/cases of death and disappearances contributes to the tone of denunciation. I believe that it is also relevant that the victims of the violence are portrayed in the discourse from "both sides". The Material process siguieron / was followed which can be considered almost as an Existential process, contributes to emphasize the climate of generalized violence that is repeated throughout the Report.

(11) No compete a la Comisión pronunciarse sobre los hechos ocurridos ese día y los inmediatamente posteriores, sobre si ellos fueron o no justificados ni sobre si existía o no otra salida para el conflicto que los originó. Además, respecto de todas estas materias pueden existir y existen, legítimamente, distintas opiniones. (...) . El conocimiento de la crisis de 1973 se hace entonces indispensable, tanto para entender la gestación de las posteriores violaciones de esos derechos que bemos debido investigar, como para prevenir que ellas se repitan. Esto, en ningún caso, como ya se ha dicho, puede ni debe entenderse en el sentido de que la crisis de 1973 justifique ni excuse, en ninguna medida, tales violaciones. (p.27)

(11) It is not the Commission's charge to declare whether or not the events that happened that day and the days that followed were justified, nor whether there were other ways to end the conflict that gave rise to these events. Moreover, in regards to all these matters, different options may and do legitimately exist (...). The understanding 
of the crisis of 1973, therefore, is of the upmost importance in order to understand the origin of the violations that we have had to investigate and to prevent them from happening again. As has already been said, it cannot and should not be understood from this that the crisis of 1973 in any way justifies or excuses these violations. (p.27)

(12) (...). No ignora la Comisión que la crisis tenía raíces más profundas, de carácter socio-económico, pero explorarlas - excepto por referencias puntuales - bubiese ido más allá de su cometido, y del objeto directo del presente capítulo. No puede, sin embargo, dejar de decir que el origen último de la crisis deberá buscarse en la lucha, a lo largo del siglo, y dentro del régimen republicano, entre los distintos y divergentes intereses sociales. (p.27)

(12) The Commission does not ignore that the crisis has deeper socio-economic root, but to explore them -except for specific references- had meant for the Commission to have gone beyond its work, and beyond this chapter's immediate purpose. The Commission cannot, however, abstain itself from saying that the ultimate origin of the crisis should be sought in the struggle -throughout the century and within the republican regime -between the distinct and divergent social interest. (p.27)

The members of the Commission shift the manner in which they present themselves, and start using a third person instead of the $1 \mathrm{p}$.plural "we". They refer to themselves as "the Commission" detaching themselves from what they are presenting. The use of the nominalization the knowledge of the crisis allows a naturalized presentation that is emphasized by la crisis de 1973/ the crisis of 1973; la crisis / the crisis; and los hechos ocurridos / the events that happened.

The negative polarity is focalized twice in example (12). The second instance of negative polarity is built with a modal verb (modulization/ obligation) that is followed by a counter-expectation conjunction "sin embargo" plus another negative expression dejar de decir/ abstain itself from saying, which because of the double negation, transforms this sentence into an affirmative one. The third instance of modulization in this example is deberá buscarse / should be sought, with the modal verb "deber" but expressed with higher intensity due to the future tense. Note that the future tense in Spanish could have a higher level of deontic meaning of obligation than the Imperative, which is mode deontic by default, because it is establishing "what is going to happen in the future", phenomenon that could be different with the use of imperative: it leaves more room for a potential refuse of the order.

The use of modulization with negative polarity works in the discourse as a way to diminish the naturalization of the past. Another very clear and 
repeated resource utilized by authors during the whole Report are the negative clauses that in several cases follow a marked syntax contributing to the Commission's self presentation as limited due to its role; they work as forms of excuse, attenuation and mitigation of the limits of the Commission's obligations.

(13) De todo ello, lo que concierne a la Comisión, y constituye por ende materia de la segunda parte de este capítulo, es cómo el régimen político 1973-1988 pudo facilitar las graves violaciones de los derechos humanos que abarca este Informe. No nos corresponde juzgar sobre las otras bondades u otros defectos de ese régimen, ni sobre sus logros o fracasos; asuntos respecto de los cuales también cabe que existan, y efectivamente existen, legítimas discrepancias. (p.27)

(13) Out of all of this, what the Commission is concerned with, and therefore constitutes the second part of this chapter, is how the political regime 1973-1988 was able to facilitate the grave human rights violations that this report deals with. It is not our task to make any judgments regarding that regime's virtues or flaws, or its achievements or failures; matters about which it is possible that there might be, and, in fact, there exist, legitimate discrepancies. (p.27)

In this example (13) authors show another shift that collaborates to reinforce the role and scope of the Commission's role. The Existential process "existan" that uses a third impersonal/unknown person in present subjunctive, portrays a modalized meaning of possibility. In addition, cabe que / it is possible that (modalization) mitigates the force of existan, which is already mitigated by the use of the subjunctive ${ }^{3}$. Later in the paragraph, the same verb is brought from the 'irrealis' to the 'realis' of the indicative mode.

(14) Según adelantábamos, el origen último de la crisis así descrita es, naturalmente, muy complejo, y está abierto a múltiples interpretaciones que no corresponde a la Comisión juzgar ni profundizar. Pero debe señalar los factores que, a su juicio, fueron más importantes para generar la polarización y la crisis, y también, por consiguiente, sus dolorosas y las más de las veces innecesarias consecuencias. (p.28)

(14) As we mentioned, the ultimate origin of the crisis we are describing is, naturally, very complex and open to multiple interpretations, which is not the Commission's task to judge or elaborate. However, the Commission must indicate the factors which, according to its understanding, were the most important ones in causing polarization and the crisis, as well as its painful and, most often, unnecessary consequences. (p.28)

\footnotetext{
${ }^{3}$ I would like to thank Mariana Achugar for her valuable suggestions on this aspect.
} 
(15) No es papel de la Comisión analizar estos bechos, pero se atreve a decir que confluyeron en ellos factores de manejo propiamente económico, y otros de índole político-social, (...). Se presentan a continuación los factores principales: (p. 30)

(15) It is not the Commission's role to analyze these facts, but it dears to say they were the result of economics factors as well as others of a social and political character (...). The main factors are now presented (p. 30)

In these two examples it is possible to observe the reiterative use of negative polarity to justify not only their lack of desire to judge but rather that they are not "allowed" to do so. This is explicit in the discourse by a common structure that uses a negative clause followed by a verbal projection introduced by a concessive: It is not the Commission's role to analyze those facts, but it dears to say...

Although the Commission's role is to identify and clarify the truth about the severe human rights violations that happened between 1973 and 1989, in the Report, its members identify groups from the extreme Left and State Agents, giving just a brief report about extreme groups from the Right. Violence from the Right is presented mainly as an escape/ salida from the crisis generated by the Left. The Left is portrayed as the initiator of the violence (they have chosen an "armed solution"), and the Right as reacting to the crisis.

The discourse continues with an exposition about the Cold War, the Cuban Revolution, and the movement of counter-insurgence in all Latin America. Authors allude to the Left wing political parties, and with special detail, they present the MIR (Movement of Revolutionary Left) and its "armed via".

(16) Si la oposición partidista no tuvo, según se ha visto, una posición tan neta de "vía armada" como la que tenían algunos sectores de Gobierno, no parece discutible que, a través de organismos políticos (partidos y Congreso) y sociales (gremios productivos y profesionales), intentó obligar a la Unidad Popular a transigir, preterir o abandonar su modelo de sociedad, colocándola en la disyuntiva de hacerlo o de enfrentar un país ingobernable. (p.30)

(16) If the opposition political parties did not have, as we have seen, a stand so determined for the "armed way" as did some sectors in the government, it does not seem arguable that through political (parties and Congress) and social (entrepreneurial and professional associations) organizations, they intended to force the Popular Unity to compromise, delay or give up its social project, leaving the Popular Unity at the disjunction of implementing that project or facing a country that would not be possible to govern. (p.30) 
Oteíza: Evaluative patterns IN THE Official DisCoURSE OF HUMAN RIGHTS...

(17) Cualesquiera que hayan sido las causas de la crisis económica, no parece discutible que ella contribuyó con singular intensidad a desarrollar la situación que desembocaría en los sucesos de 1973. (p.30)

(17) Whatever the causes of the economic crisis might have been, it does not seem arguable that it contributed with singular intensity to unfold the situation that would end in the events of 1973. (p.30)

Example (16) as other previous ones shows how authors are looking for an ideological solidarity with the reader by the use of impersonality and Verbal/Mental processes. I think that it is interesting how "what happened" is presented as a generalized past in the discourse. "What happened" is presented in a confusing manner in the discourse, as the final crisis of Allende's government, the September $11^{\text {th }}$ coup d'etat, and the human right violations. All of these events are portrayed as a "violent social environment" reinforced by the rhetorical repetition of the final crisis. Although these severe violations are not "justified", authors do offer an explanation and judgments of Social Esteem and Social Sanction. Lo ocurrido, expressed mainly by this neutral pronoun "lo" + an existential process, is the past that all Chileans need to remember as a sad episode of which we are all responsible as a society. We must lament, turn over the page and do not search for real explanations or real reflections, as many other CDA analysis have shown about traumatic events around the world (Achugar 2004, 2008; Augoustinos et. al. 2002; Butt, lukin \& Matthieseen 2004; Martin 2004b; Oteíza \& Pinto 2008, among many others). The authors of the Report continue with the identification of the Armed Forces' role in the human rights violations. They give room to explain the secretive procedures of the DINA (National Direction of Intelligence, CNI since 1978, National Information Center). The first volume of this Report finishes with pages and pages of victims with a brief narrative of what the Commission was able to establish about the truth of their death. In the majority of the cases the Report states that they were victims of official agents or product of the generalized climate of violence that the country lived mainly during 1973 and 1974.

Later on in the discourse, the Commission emphasizes, with a strong use of high modality adjuncts and polarity: inevitably, it is indisputable, a climate obviously conducive to a civil war; inavitability, among many others the inevitability of the coup d'etat. Authors emphasize the role of mass media 
of both sides which created more violence that "prepared the path for the fear that engendered hate, which in turn leads to brutality and death". Therefore, the "brutality" and "death" are part of a whole climate; it is an argument that indirectly reinforces society's responsibility as a whole.

I do not have space in this paper to present in detail the analysis of how the Right, the Armed Forces and DINA are represented in the discourse. However, I would like to mention that the Commission tries repeatedly to avoid making judgments about their responsibility. This makes a contrast between the strong social and moral responsibility attributed by this official document to all Chileans, and the forgiveness, attenuation and apparent justification of the Armed Forces.

\section{The past as a "closed box"}

The main findings of the analysis can be summarized in the following two tables that intend to demonstrate the main rhetoric patterns used by the members of the Rettig Commission:

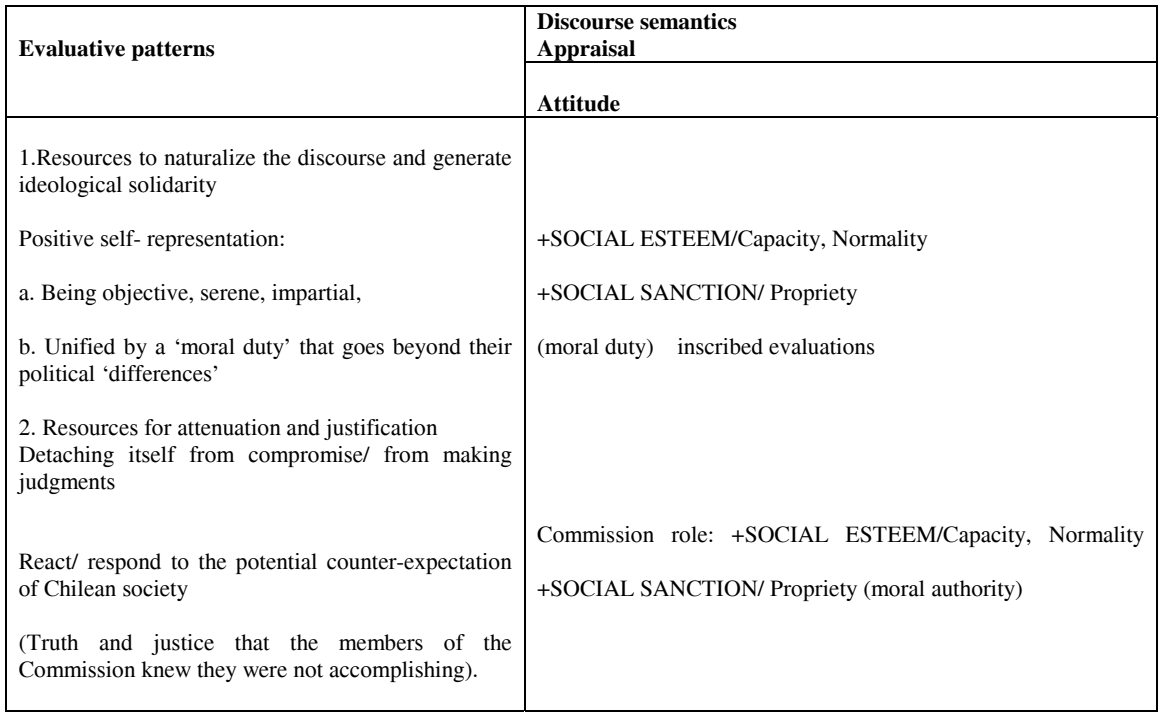

Table 1: Commission self-representation. 
Oteíza: Evaluative patTerns In THE OFFicial discourse OF HUMAN RIGHTS... 633

\begin{tabular}{|c|c|}
\hline \multirow[t]{2}{*}{ Evaluative patterns } & $\begin{array}{l}\text { Discourse semantics } \\
\text { Appraisal }\end{array}$ \\
\hline & Attitude \\
\hline $\begin{array}{l}\text { Obligation of assuming a social and moral } \\
\text { responsible role about "what happened" }\end{array}$ & $\begin{array}{l}\text {-SOCIAL SANCTION/ Propriety (responsible for the violence } \\
\text { and human right violations) inscribed and evoked (indirect } \\
\text { responsibility) }\end{array}$ \\
\hline $\begin{array}{l}\text { "Essential identity": reasons to contribute to } \\
\text { Chileans's reconciliation }\end{array}$ & $\begin{array}{l}\text { Chilean' duty: +SOCIAL SANCTION/ Propriety; +SOCIAL } \\
\text { ESTEEM/ Normality (Chilean's reconciliation) inscribed }\end{array}$ \\
\hline $\begin{array}{l}\text { The way "we" need to think and the way "we" need } \\
\text { to act. }\end{array}$ & $\begin{array}{l}\text { +AFFECT/ Happiness (Chileans's reconciliation) evoked. } \\
\text { +APPRECIATION/Social Value) inscribed }\end{array}$ \\
\hline Common desire of reconciliation. & \\
\hline The "others": "the dissidents/ the Left is excluded & -AFFECT/ unhappiness (past) evoked \\
\hline
\end{tabular}

Table 2: Chilean Society evaluated by the Commission.

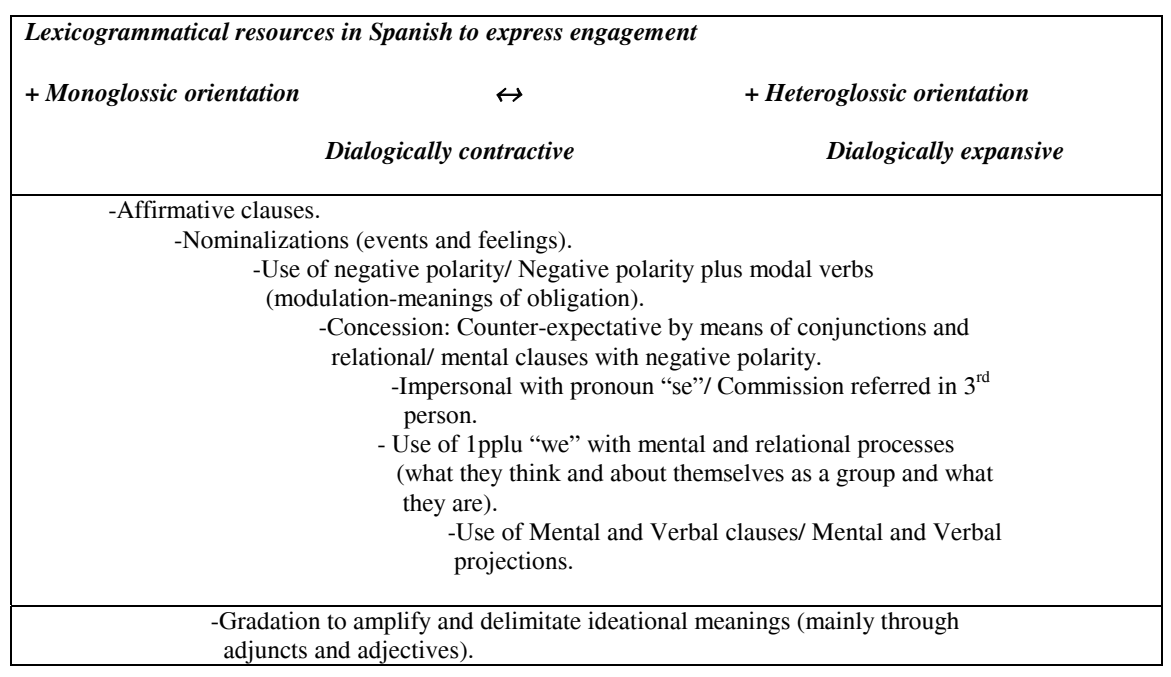

Figure 1: Commission self-representation. 


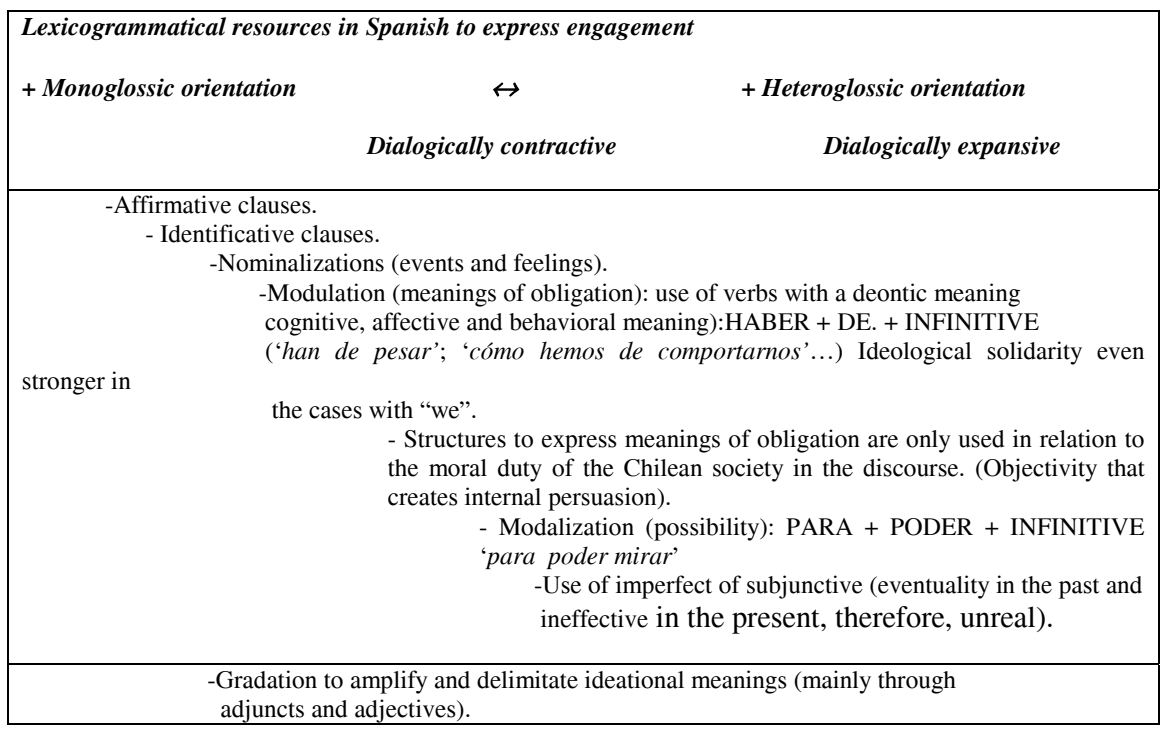

Figure 2: Chilean Society evaluated by the Commission.

The analysis of the Rettig Report that I have presented is the beginning of a larger research with a broader corpora of official documents and historians' interpretations that I would like to pursue. In this way, I expect to be able to validate the readings of evaluations in a more generalized manner, detecting how meanings are primed in readers' positions. (Baker et al.2008; Coffin \& O'Halloran 2006; Wodak \& De Cilia 2007). Although as analysts, it is impossible to avoid subjectivity when interpreting because we are part of discursive communities. Nevertheless, from an intertextual perspective, if we take into consideration how the past has been portrayed in Chilean history textbooks, it is possible to conclude that the representation of Allende's government and the justification of the coup d'etat in the Report have remained the same overtime than the one expressed in textbooks published between 1993-2006. As Oteíza \& Pinto concluded about Chilean history textbooks published for 2005-2006: "In spite of a discourse that in both Chilean textbooks attempts to present different perspectives, the authors collectivize and unite the Chilean society by representing them as a whole that 'plea' for the Armed Forces intervention. This position rests on the fear, insecurity and threat of a Marxist regime, 
and on the crisis that the country experienced, especially during the last period of Allende’s government." (Oteíza \& Pinto 2008:355).

The Rettig Commission, as an official voice that acted within the limits of "justice, within the possible" and whose members were from the Right and Center political spectrum of the country, offers a hegemonic and established reading of the past. Their Report was the document in which President Aylwin based his apology to victims of human rights violations on behalf of all Chileans on March 4, 1991. The members of the Commission negotiate solidarity with Chileans as a whole, and promote a moral rejection of the 'dissidents' that created polarization and extreme violence. This position could be considered in itself a monoglossic orientation, because this "other" represents the Left that was not invited to be part of the Commission, not even taking into consideration the negative Social Sanction evaluation that is indirectly associated with it.

The members of the Commission engage with their readers from a superior moral status ("moral authority") to tell Chileans the ways of revisiting the past. They tell us about the 'spiritual attitude' with which we need to behave, think and feel about this past. From their 'different perspectives' they are sending us a strong message of closing our discrepancies and the necessity that we all align around a "common desire of reconciliation'.

According to Stern (2006), the past is remembered with contradictory memories by people from different sectors of the Chilean society. Among these competing conceptual frames of remembering the past as "salvation", "rupture", "persecution and awakening" or as a "closed box", this last one is especially privileged by the members of the Commission. In the Report's analysis I have tried to demonstrate that this past is portrayed mainly as a well arranged package, or as a block, in the sense that all "what happened": Allende's government crisis, the military coup d'etat, and the severe human rights violations, is packaged creating a closed social establishment, both in an ideological and axiological sense. In this closed "box", the events, our reactions (feelings and thoughts) are ready for us, as a given. We can conclude that there is little room for counter-hegemonic positions in the Report.

I postulate that this 'closed box' as Stern denominated it, does not imply that we do not have to think about the past, but rather that our 
historical memory needs to contribute to overcome social and political polarizations that divided the country. Clearly a polarized society does not meet the purpose of a reconciliatory and consensual community that is looking to the future. Therefore, the 'reflection' that the Commission is asking for is also delimitated, is about the horror of human rights violations and not about explanations about what happened, and even more remotely about responsibilities and justice.

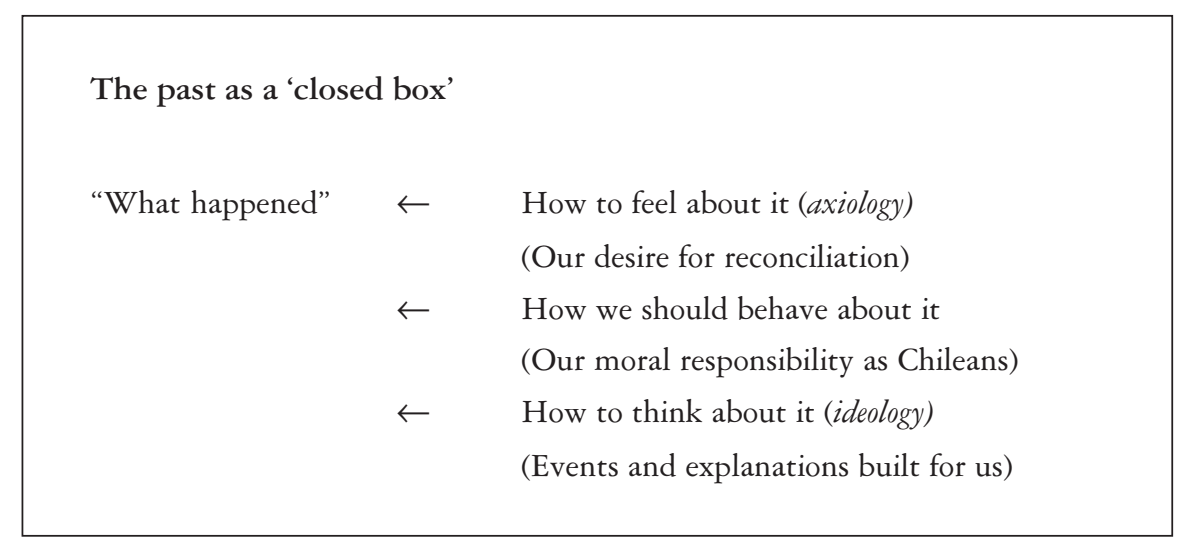

Figure 3: Revisiting the past from a hegemonic view.

In the Rettig Report evaluation works greatly as a saturated prosody. However, what seems more relevant is the use of a dominating prosody connected to the members of the Commission's self-representation. This rhetoric evaluative pattern in which the first element of the clause or sentence dominates the interpersonal meaning (Martin \&White 2005), clearly serves as a justification for the Commission's limitations. This is achieved through the repeatedly use of negative polarity in relational and mental clauses (It is not the Commission's charge; It is not the Commission's task to make any judgments, among many others) as the analysis have shown. I believe that this negative polarity functions in the discourse as a dominant prosody at two levels: an epistemic and a dialogic one. The bakhtinian's notion of the essential dialogic nature of every text lead us necessarily to take the reader more into consideration in the analysis. Consequently, if we take into account, that after seventeen years of dictatorship and thousands of people death and relatives waiting to find them or to see justice being served, the Rettig Report created an enormous expectation 
OTEÍZA: EVALUATIVE PATTERNS IN THE OFFICIAL DisCOURSE OF HUMAN RIGHTS... 637

for closure among Chileans, even knowing the restricted circumstances in which the Commission worked, the little collaboration they received from the militaries and the under-representation of the Left in the group.

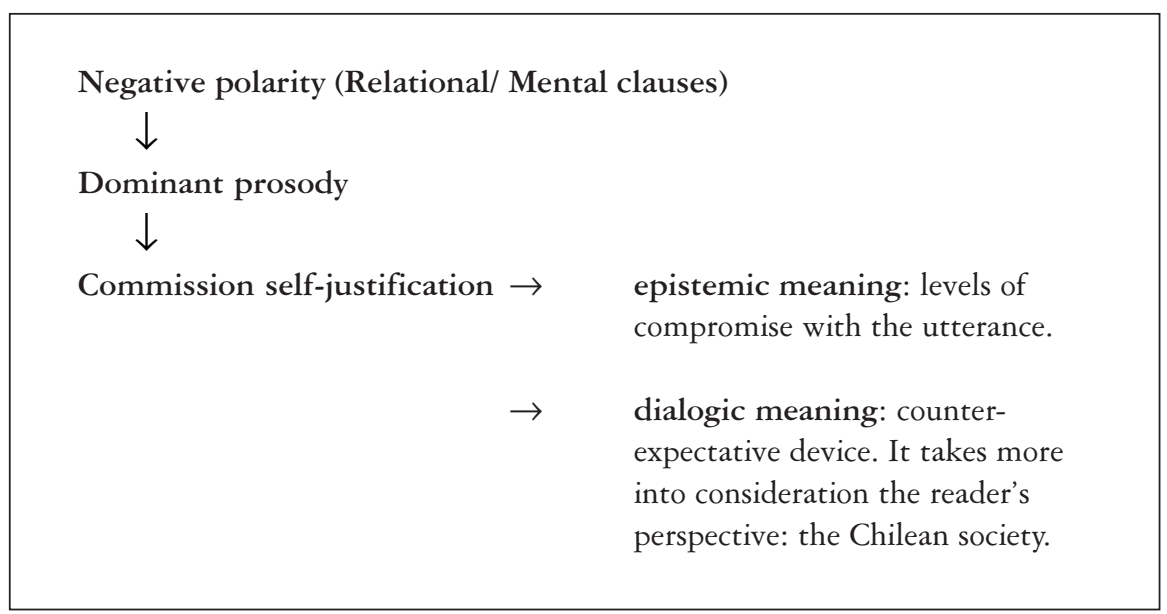

Figure 4: Negative polarity as a dominant prosody.

The Commission is not only justifying their limitations, but it is also reacting from the potential hope of Chileans that where waiting with a desire of truth and justice. This negative polarity works as a counterexpectation resource throughout the discourse. What people "desired" from the Report and the transition as a whole, and what really happened.

E-mail: teresaoteiza@uach.cl

\section{REFERENCES}

ACHUGAR, M. 2008. What we remember: the construction of military memory. John Benjamins.

. 2004. The events and actors of 11 September 2001 as seen from Uruguay: analysis of dayly newspaper editorials. Discourse $\mathcal{E}$ Society, 15(2-3): 291-320.

Achugar, M. and M. Schleppegrell. 2005. Beyond connectors: The construction of cause in history textbooks. Linguistics and Education, 16: 298-318. 
Augoustinos, M, A. Lecouteur, and J. Soyland. 2002. Self-sufficient Arguments in Political Rhetoric: Construing Reconciliation and Apologizing to the Stolen Generations. Discourse E Society, 13(1): 105-142.

Baker, P, C. Gabrielatos, M. Khosraninik, T. Mkrzyzanowski, T. Mcenery Y and R. Wodak. 2008. A useful methodological synergy? Combining critical discourse analysis and corpus linguistics to examine discourses of refugees and asylum seekers in the UK press. Discourse E Society, 19(3): 273-306.

BaKhTIn, M.M. 1991. The Dialogic Imagination. Austin: University of Texas Press.

1985. Estética de la creación verbal. Segunda edición en español.

Coyoacán: Siglo veintiuno editores.

Bartlett, T. 2004. Mapping Distinction: Towards a Systemic Representation of Power in Language. In: L. Young \& C.Harrison. Eds. Systemic Functional Linguistics and Critical Discourse Analysis. Studies in Social Change. London/New York: Continuum.

Butt, D, A. Lukin and C. Mattiessen. 2004. Grammar- the first covert operation of war. Discourse E Society, 15(2-3): 267-290.

Chouliaraky, L. and N. Fairclough. 1999. Discourse in late modernity. Retbinking critical discourse analysis. Edimburgo: Edingburgh University Press.

Cofrin, C. 2003. Reconstruals of the Past - Settlement or invasion? The role of Judgement Analysis. In: J. R. Martin \& R. Wodak. Eds. Re/reading the Past Amsterdam/Philadelphia: John Benjamins Publishing Company. 2006. Historical discourse: the language of time, cause and evaluation. London, New York: Continuum.

Coffin, C. and K. O'Halloran (2006). The role of appraisal and corpora in detecting covert Evaluation. Functions of Language, 13(1): 77-110.

Correa, S., C. Figueroa, A. Jocelyn-Holt, C. Rolle and M. Vicuña. 2001. Historia del siglo XX Chileno. Santiago-Chile: Editorial Sudamericana.

Fairclough, N. 1995. Critical Discourse Analysis. The Critical Study of Language. London: Logman. . 2003. Analysing Discourse. Textual analysis for social research. London/ New York: Routledge.

Fairclough, N. and R. Wodak. 1997. Critical Discourse Analysis. In: T. van Dijk. Ed. Discourse as Social Interaction. London: Sage.

FontanA, J. 1992. La historia después del fin de la historia. Reflexiones acerca de la situación actual de la ciencia histórica. Barcelona: Crítica. 
FOUCAUlt, M. 1972. The archaeology of knowledge and the discourse of language. New York: Pantheon Books.

Graham, P. 2004. Predication, Propagation, and Mediation: SFL, CDA, and the Inculcation of Evaluative-Meaning Systems. In: L. Young and C. Harrison. Eds. Systemic Functional Linguistics and Critical Discourse Analysis. Studies in Social Change. London/New York: Continuum.

Halliday, M.A.K. 1994. An Introduction to Functional Grammar. London: Edward Arnold.

Halliday, M.A.K. and Matthiessen. 2004. An Introduction to Functional Grammar. London:Edward Arnold. Third Edition.

Hunston, S. and Thompson, G. 2000. Evaluation in Text. Oxford: Oxford University Press.

Jelin, E. 2002. Los trabajos de la memoria. Madrid: Siglo Veintiuno de España Editores, S.A.

Lemke, J. 1995. Textual Politics: Discourse and Social Dynamics. London: Taylor \& Francis.

Loveman, B. 2001. Chile. The Legacy of Hispanic Capitalism. New York: Oxford University Press. Third edition.

Martin, J. R. 1997. Analysing Genre: Functional Parameters. In: F. Christie \& J. R. Martin. Eds. Genre and Institutions: Social Processes in the Work Place and School. London: Continuum.

2000. Beyond Exchange: Appraisal Systems in English. In: S. Hunston \& G. Thompson.Eds. Evaluation in Text. Oxford: Oxford University Press. 2002. Writing History: Construing Time and Value in Discourses of the Past. In: M.Schleppegrell \& M. C. Colombi. Eds. Developing Advanced Literacy in First and Second Languages: Meaning with Power. Mahwah, NJ: Lawrence Erlbaum Associates. . 2003a. Introduction. Text, 23(2):171-181. Special Issue. Negotiating Heteroglossia: Social Perspectives on Evaluation. MackenHorarik, M.\& J.R. Martin. Eds. . 2003b. Making history: Grammar for interpretation. In: J.R. Martin \& R. Wodak. Eds. Re/reading the Past. Critical and functional perspectives on time and value. Amsterdam/Philadelphia: John Benjamins Publishing Company. 2004a. Sense and Sensibility: Texturing Evaluation. In: J. A. Foley. Ed. Language, Education and Discourse: Functional Approaches. London: Continuum. 
. 2004b.Mourning: how we get aligned. Discourse E Society, 15(23): 321-344.

Martin, J. R. and Rose, D. 2003. Working with Discourse. London: Continuum.

Martin, J.R. and White, P. 2005. The Language of Evaluation. Appraisal in English. New York: Palgrave Macmillan.

Martin, J.R. and R. Wodak. 2003. Eds. Re/reading the Past. Critical and functional perspectives on time and value. Amsterdam/Philadelphia: John Benjamins Publishing Company.

MaUter, G. 2005. Time to get wired: Using web-based corpora in critical discourse Analysis. Discourse E Society, 16(6):809-828.

Oteíza, T. 2003. How Contemporary History is Presented in Chilean Middle School Textbooks. Discourse \& Society, 14(5): 639-660. .2006. El discurso pedagógico de la historia. Un análisis lingüistico sobre la construcción ideológica de la historia de Chile (1970-2001). Santiago, Chile: Frasis editores.

(forthcoming Revista Signos). Solidaridad ideológica en el discurso de la historia: tensión entre orientaciones monoglósicas y heteroglósicas.

Oteíza, T, and D. Pinto. 2008. Agency, Responsibility and Silence in the Construction of Contemporary History in Chile and Spain. Discourse E Society, 19(3): 333-358.

Pardo AbRIL, N. 2007. Cómo hacer análisis crítico del discurso. Una perspectiva latinoamericana. Santiago: Frasis.

Stern, S. 2006. Remembering Pinochet's Chile. On the Eve of London 1998. Durkam \& London: Duke University Press.

Troulllot, M. 1995. Silencing the Past. Power and the Production of History. Boston: Beacon Press.

Van Leeuwen, T. y R. Wodak. 1999. Legitimizing Immigration Control: A Discourse-Historical Analysis. Discourse Studies, 1(1): 83-118.

White, P.R.R. 2000. The appraisal website. http://www.Grammatics.com/ appraisal/. Last update: March, 5th, 2005.

White, P.R.R. 2003. Beyond modality and hedging: A dialogic view of the language of intersubjective stance. Text, 23(2): 259-284

WodAK, R. and De Cilia. 2007. Commemoring the past: the discursive construction of official narratives about the 'Rebirth' of the Second Austrian Republic. Discourse E Communication, 1(3): 337-363. 